\title{
The Realistic Dilemma, Value Implication and Realization Path of the Education of Socialist Core Values in Colleges and Universities
}

\author{
Hongmei Fang ${ }^{1}$ \\ ${ }^{1}$ College of Marxism, China Jiliang University, Hangzhou 310018, China \\ *Corresponding author. Email: 1269457884@qq.com
}

\begin{abstract}
The education of socialist core values in colleges and universities is faced with realistic dilemma of disciplinary diversity, complex carriers and fragmented content. In-depth grasp of the laws of education, theoretical innovation and philosophical wisdom contained in the education of socialist core values, and focus on exploring the "three-in-one" combination of socialist core values in the practice of colleges and universities, that is, adhere to the combination of enhancing the subject and object trust with the optimization of the team structure, the combination of innovativing the communication platform and strengthening real-time monitoring, and the combination of top-level design and enriching the specific content.
\end{abstract}

Keywords: Colleges and universities, Education of socialist core values, Realistic dilemma, Value implication, Realization path.

\section{INTRODUCTION}

President Xi Jinping pointed out, "Youth are the social forces that lead the way, and the civilization of a nation is largely reflected in the moral standards and spiritual outlook of the younger generation." [1] Colleges and universities play an important role in mainstream ideological education for young people. And the socialist core values embody the common values pursuit of all college students and are the value norms that regulate behavioral cognition. At present, the education of socialist core values in colleges and universities is facing multiple difficulties. In-depth grasp of the connotation and meaning of the education of socialist core values in colleges and universities, and focus on exploring the implementation and realization of the socialist core values in colleges and universities, so that college earnestly youth can start from themselves internalize the socialist core values into their own basic principles, and conscientiously promote them to the whole society.

\section{THE REALISTIC DILEMMA OF SOCIALIST CORE VALUES EDUCATION IN COLLEGES AND UNIVERSITIES}

\subsection{The Diversification Diversity Weakens the Authority of Core Values Education}

Traditional core values education in universities are dominated by a single subjesct, while the development of the times and Internet technology has made the core values subjects of universities diversified with flexibility, variability, and openness, and promoted the unidirectional education of core values in universities from ideological and political teachers to students. The degree theory instillation is transformed into a fourdimensional interactive communication from ideological and political teacher to student, student to student, student to the ideological and political teacher and student self-reflection. At the same time, while colleges and universities are carrying out core value education, every student backbone, class assistant, counselor, class teacher, course teacher, and leading cadres of various departments have failed to effectively penetrate the core values education into every corner of the campus. Focusing on current affairs, integrating the 
latest methods and means, and the coupling of the education subject and education content. Therefore, the authority of core values education information transmission and the monopoly of discourse transmission in colleges and universities have been weakened. The expected effect of the political guidance and moral cultivation function of core values education is not satisfactory. The one-dimensional classroom teaching of core value education has failed to achieve practical results, and the role of teachers as a"gatekeeper" is weakened in the core values education of colleges and universities, thereby undercutting the authority of core values education, and objectively has a higher grasp of the structure and team level of the core values education subject of colleges and universities.

\subsection{The Complexity of the Carrier Increases the Difficulty of Dissemination of Core Values Education}

The education carrier of core values in colleges and universities upgrades offline learning to a dual combination mode of real activities and network virtuality. Due to the limitations of the scope of real activities, the complexity of the approval process, and the low participation of the educated, the core values education coverage is narrow, the frequency of activities is low, and the poignant remarks from educatee is plentiful, which cause colleges and universities to shift their attention to the online virtual model. Colleges and universities use platforms such as Weibo, WeChat, Micro Video, and clients to break the virtual "presence" of time and space barriers to produce emotional experience and atmosphere rendering. However, the enslavement and alienation of modern new media and the curiosity of college youths, the normalization of core values has not been popularized. The advanced Internet technology provides real-time information for college youths and modernizes the media to better meet the urgent needs of student groups for value standards and behavioral orientation. Meanwhile, it provides core values education with negative material for moral anomie. The concealment and equality of the Internet give college youths the power to fully express themselves in the cyberspace, and increase the possibility of cybercrime. The cheap cost of default in cyberspace makes it difficult to curb moral anomie. Once colleges and universities fail to respond to moral anomie in a timely manner on the Internet, it will have a series of adverse effects, which will make college youths question the mainstream values.

\subsection{Content Fragmentation Impacts the Actual Effect of Core Values Education Practice}

Each age is conceived with the unique spirits of each age, and each generation is branded with the unique values of each generation. The core values of socialism are the "greatest common divisors" proposed in the new era to reflect the common values of the people of all ethnic groups in the country around what kind of country and society should be built and what kind of citizens should be cultivated. It is a common value related to the future and destiny of the country and the health and well-being of the people. President $\mathrm{Xi}$ pointed out in his speech at the Peking University teacher-student symposium, "The value orientation of youth determines the value orientation of the entire society in the future, and youth is in a period of value formation and establishment, which is important to cultivate values in this period."[1] Therefore, when the three views of youth are not form, they must be educated to buckle the first button of life. However, in the modern Internet era, the massive fragmented information affects the macro, meso, and micro emotional needs of the core values education of colleges and universities, and impedes the urgent need for young people to realize the organic integration of national, social and self-values. At the same time, the dual combination of real activities and network virtuality makes the content of value education diversified, and makes various false and wrong ideologies and values widely disseminated among college youth groups. In particular, the value penetration and discourse hegemony of various Western media have created severe challenges for college youths to cultivate correct moral cognition, conscious moral development and active moral practice. College youth who have been in the "subculture" space of new media for a long time lack the awareness of distinguish good and bad Internet culture. They often have no opinions of their own but simply follow the herd, which also profoundly affects the actual effect of core values education. In short, the psychological immaturity of college youth, the development of new media, and the sharing of educational information increase the risk of ideological education in colleges and universities, and easily lead to difference in the identification of mainstream values among college youths.

\section{THE VALUE SIGNIFICANCE OF SOCIALIST CORE VALUES EDUCATION IN COLLEGES AND UNIVERSITIES}

\subsection{The Education of Core Values Contains the Law of Ideological and Political Education}

The core values education of colleges and universities serves as a foundation project that guides young students to respect morality, learn morality, abide by morals, and pursue lofty moral ideals. It does not only focus on the cultivation of students' moral sentiment, but also focuses on the development of "Prosperity and strength, Democracy, Civilization and Harmony" to promote great virtues of young people in colleges and universities to love the people of the 
motherland and strengthen their ideals and beliefs. For a long time in the past, college youths have been immersed in historical nihilism, neoliberalism, and individualism. These bad thoughts have instigated society by slandering our country's historical facts, heroes, national leaders, and state system, which undermines the college youth's identity and loyalty to our country's roads, theories, systems and cultural confidence. Therefore, it is particularly necessary to attach great importance to national values to cultivate a sense of national identity and national belonging, so that college youths should bear the responsibility of "doing whatever it takes to serve one's country even at the cost of one's own life, regardless of fortune or misfortune to oneself.". With "freedom, equality, justice, and the rule of law", we will cultivate the public morality of college youth to observe discipline and law, fairness and justice. Core values education introduces the common value orientation at the social level, vividly analyses the positive and negative cases online and offline, and guides young people to understand, abide by, and practice public ethics, adheres to "a public spirit will rule all under the sky when the great way prevails.", and shoulders the social responsibility of the ancient civilization. With "patriotism, dedication, integrity, and friendliness", we promote the personal virtues of honesty, empressement, and mutual help among college youths. Core values education takes personal morality and accomplishment as the third aspect, which integrate the labor, occupation, and moral education in college ideological and political education to cultivate students with correct life orientation and persist in creating extraordinary greatness from ordinariness.

\subsection{The Education of Core Values Contains the Innovative Transformation of Marxist Theory}

Marxist theory is a scientific theory that advances with the times and continues to develop. It still has strong vitality and value space in the new era of socialism with Chinese characteristics. Its vitality is reflected in its clarification about the law of value for the development of human society from the perspective of dialectical materialism and historical materialism. At the same time, it's also reflected in constantly venting the old and adding to the new in the changes of the times, realizing its own leap-forward development. Core values education is the production of Marxist theory based on the basic national conditions and the main contradictions. It provides a comprehensive view of the human development theory and the comprehensive explanation of the essential power of human beings contained in the Marxist theory from a macro country perspective, a meso social perspective, and a micro individual aspect. As Marx pointed out: "Anyone's duty, mission, and task are to develop all their abilities in an all-round way." [2] The core values education of colleges and universities is conducted through five aspects of morality, intelligence, physical conditions, mind status and community service to realize the ardent hopes of modern society for the young generation, so that university youths will continue to innovate and deepen Marxism while achieving the "Five Learnings".

\subsection{The Core Values Education Contains Chinese Excellent Traditional Philosophical Wisdom}

As the cultural gene of the Chinese nation for thousands of years, the excellent traditional Chinese culture contains inspiring and thought-provoking philosophical wisdom, deeply roots in the hearts of the people, and subtly affects the way of thinking and behavior of Chinese people. The ancients said: "What the Great Learning teaches, is to illustrate illustrious virtue; to renovate the people; and to rest in the highest excellence."[3] The core values, as a kind of virtue, contain personal virtue, national ethics and social morality. Today, the promotion and cultivation of core values in colleges and universities is to continuously assimilate nourishment from the excellent Chinese traditional philosophical wisdom, and to understand that "People are the Base of a Country", "Union but difference" [4] "Manners make the man", "Proper norms should be observed to uphold peace"; explain the value principle of "Everyone should be concerned about the rise and fall of the world", "Keeping his word and seeing his actions"[4], "A gentleman is open and poised"[4]; practice The benevolent loves others" [5], "Be kind to others" [5], "mutual help and protection" [5], "Help the poor" behavior standards. Due to its distinctive national character, timeless value, continuity and stability, the excellent traditional Chinese philosophy keeps advancing with the times and innovating in the course of historical changes. It has been condensed into the mainstream values respected by today's society and has become one of the important contents of values education in universities.

\section{WAYS TO PRACTICE SOCIALIST CORE VALUES IN COLLEGES AND UNIVERSITIES}

\subsection{Strengthen the Combination of Subject and Object Trust and Optimization of Team Structure}

Ideological and political education usually conducts investigation and research in the three-dimensionality of "subject-method-object". The core values education of colleges and universities should take the threedimensionality as a standard, strengthen the emotional cultivation of subject and object, innovate working methods, and effectively strengthen the effectiveness of core value education. First of all, colleges and 
universities should adhere to the "people-oriented" principle to integrate internal and external resources, and use the Internet, big data, new media, and artificial intelligence to aggregate and transform the needs, preferences, and emotional expressions of college youth and other technical advantages, and establish the communication bridge between teachers and students through teacher-student interaction. The communication bridge of the spiritual world generates emotional resonance and belief support, enhances the effective trust between the subject and the object, and provides the possibility for the core values of "precise irrigation". Secondly, large education funding investment, implementation of ideological and political teacher post allowances, the introduction of compound talents with multidisciplinary backgrounds such as management, journalism, psychology, etc, to create a major ideological and political team that understands the moral needs of students and can accurately grasp the connotation of core values, so that teachers and students in colleges and universities will stimulate the practice of socialist core values in the context of emotional mutual trust and high-frequency interaction, and strengthen the intrinsic needs and value recognition of individual young students for the core values.

\subsection{Combination of Innovative Communication Platform and Enhanced Real- time Monitoring Mode}

In the information age, college party committee cadres, ideological and political teachers should organically integrate online and offline dual-channel parallel models. Innovate the form of discourse dissemination, accept the established situation in which the education of core values of colleges and universities has been transformed from "monologue" by teachers to "dialogue", and grasp the scale of "gatekeeper" to build a communication platform close to the needs of students. Improve the prevention and control work in the field of ideology, improve the risk investigation and judgment mechanism, conduct a comprehensive analysis of the dual-channel core values dissemination dynamics, study and judge risk points and sources of turbulence, reasonably set up hot topic sections, and guide young people to do online "public opinion guidance", deeply integrate offline "moral indoctrination". Synchronous monitoring should be used to find out and obtain the dynamic information of college youth in a timely manner. And the punishment of moral anomie should be combined with the psychological protection of students. In the face of special periods such as epidemic prevention and control and college graduation seasons, it will carry out key monitoring, through the analysis and survey of public opinion data on campus cards, "flow accounts" and "Internet", firmly grasp the initiative of ideological work, and sing the main melody in student gathering places. Moral anomie of college students is stifled in the cradle. At the same time, colleges and universities should classify students. The publicity department, psychology department and student associations of universities should conduct effective core values education based on the results of data analysis, so as to ensure that each student integrates personal development into the development of the country. "The self of youth, to create the home of youth, the nation of youth, the human beings of youth, the earth of youth, the universe of youth". [6]

\subsection{Combination of the Top-level Design and the Enrichment of Specific Content}

"On reaching the last leg of a journey, you are only half way there." Colleges and universities should earnestly grasp the top-level design, carry forward the excellent tradition of "the party has a call, the league has action", and find the entry point and combination of work in the overall situation of the party and the country, and integrate into the university core values education work, strive to build a broader stage for young students' moral practice, provide richer opportunities to create a colorful life and more convenient conditions to make contributions, so that young students can truly feel the care of the party and the country, so as to take practical actions to give back to society and promote social progress. At the same time, colleges and universities should enrich the connotation of core values, give full play to the role of young moral models, and use youth models to lead college students to redouble their efforts, be strict with themselves, and keep making progress. Personal dreams add a powerful youth to the realization of the Chinese dream. Do a good job in the overall deployment of the core values of colleges and universities, and take the "three obediences and four virtues" as the core values education content, that is, to guide the young people of colleges and universities to engage in voluntary service, engage in poverty alleviation, help the weak and the disabled, and engage in a series of civilized new style activities such as "learning from Lei Feng" activities. Advocate social ethics in the new era with those based on law-abiding, fairness and integrity, unity and mutual assistance, professional ethics based on love and dedication, diligence and courage, family virtues based on family harmony, orderly growth, and neighbourhood mutual assistance, and accommodate the personal morality of integrating public morality, morality and virtues.

\section{CONCLUSIONS}

In short, facing the severe challenges of discipline diversification, carrier complexity, and content fragmentation, the core values education of colleges and universities should deeply understand the law of ideological and political education, the Marxist theoretical innovation based on the theory of human 
development, and the extensive and profound philosophical wisdom of the Chinese nation, and have always been able to effectively integrate the strengthening of subject and object trust into the improvement of the teacher team structure to improve the teacher-student relationship, effectively combine the modern innovative communication platform and realtime monitoring to promote the effectiveness of communication, and embed colourful specific contents in the top-level design to add interest to core values education, and ultimately promotes the sustainable development of core values education.

\section{REFERENCES}

[1] Xi Jinping. Xi Jinping on State Administration (Volume One) [M]. Foreign Languages Publishing House: Beijing, 2018: 49. (In Chinese)

[2] The Compilation Bureau of Marx, Engels, Lenin and Stalin of the CPC Central Committee. The Complete Works of Marx and Engels (Volume 3) [M]. People's Publishing House: Beijing, 2014: 354.(In Chinese)

[3] Yu Yong, Fan Weijun, Fu Linpeng Note. The Book of Rites: University. The Golden Mean [M]. Changchun Publishing House: Jilin, 2013: 47. (In Chinese)

[4] Yang Bojun, Yang Fengbin's translation and annotation. The translation of The Analects [M]. Yuelu Publishing House: Changsha, 2020:1. (In Chinese)

[5] Fang Yong. Mencius [M].Business Press: Beijing, 2017: 25 th (In Chinese)

[6] Li Dazhao. The Red Tibet.New Youth.Volume Two-Number One [M]. Xiangtan University Press: Hunan, 2014: 219. (In Chinese)

[7] Zhu Qin, Huang Hongfa. Discussion on emotional education of socialist core values in the Internet era [J]. School Party Building and Ideological Education, 2021, 07: 37-40. (In Chinese) 